\title{
WORDSWORTH IN HYDERABAD: IDENTITY CRISIS IN MEENA ALEXANDER'S NAMPALLY ROAD
}

\author{
WORDSWORTH HAYDARABAD’DA: MEENA ALEXANDER'IN NAMPALLY ROAD \\ ROMANINDA KIMLIKK BUNALIMI
}

Sezer IKIIZ ${ }^{2}$

\begin{abstract}
Meena Alexander is an Indian poet, scholar and writer. Exile, identity crisis, search for roots, migration are discussed in the works of her. Meena Alexander's first novel, Nampally Road (1991) is not an exception. This short novel is also about displacement and the protagonist's attempts to create herself an identity in her native land, India. The protagonist is Mira Kannadical. She is an English lecturer who returns to her own country after studying in England for four years and getting a $\mathrm{PhD}$ on Wordsworth from Nottingham University. She is uncomfortable and alone in England and decides to return her home country. Mira wants to meet new people and see new places. So, she accepts a teaching position in Hyderabad. Hookha and Shikha assert that "all Mira's hopes and dreams are shattered to see a totally different picture of India which teems with violence, civil unrest, and turbulence" $(2013,2)$. Mira finds herself trapped in the city. She starts to question her own thoughts and writings. This paper aims to explore the conflicts in the protagonist's life and identity crisis she experiences while searching for her self with the portrayal of socio- political changes in Contemporary India.
\end{abstract}

Keywords: Meena Alexander, Nampally Road, displacement, identity crisis.

\section{$\ddot{\mathbf{O} z}$}

Meena Alexander Hintli bir şair, akademisyen ve yazardır. Sürgün, kimlik krizi, kökleri arama ve göç konuları eserlerinde tartışılmaktadır. Meena Alexander'ın ilk romanı Nampally Road'da bir istisna değildir. Bu kısa roman, yer değiştirme ve ana karakterin kendi yurdunda kendine bir kimlik yaratma çabaları hakkındadır. Mira Kannadical romanın baş kahramanıdır. İngiltere'de dört yıl kalıp İngiliz Edebiyatında doktorasını tamamladıktan sonra Hindistana döner. İngiltere'de rahatsız ve yalnız hissetmektedir. Yeni insanlarla tanışıp yeni yerler görmek istemektedir. Bu nedenle Hyderabad'da bir iş teklifini kabul eder. Hooha Ve Shikha, Mira'nın bütün umutlarının ve hayallerinin tamamıyla farklı şiddet, huzursuzluk ve kargaşa dolu bir Hindistan görünce yıkıldığını iddia eder. Şehirde kendini kapana kısılmış gibi hisseder. Duygularını ve yazdıklarını sorgulamaya başlar. Bu çalışma, başkarakterin yaşadığı çelişkiler ve kendi kimliğini ararken yaşadığı kimlik bunalımı Çağdaş Hindistanın sosyopolitik değişimleriyle birlikte incelemeyi amaçlamaktadır.

Anahtar kelimeler: Meena Alexander, Nampally Road, yer değiştirme, kimlik bunalımı.

\footnotetext{
${ }^{1}$ This study is the revised and expanded version of a paper presented at 10th International IDEA Studies on 1416 April 2016, Boğaziçi University, İstanbul.

${ }^{2}$ Dr.Öğr.Üyesi, Muğla Sıtkı Koçman Üniversitesi, Eğitim Fakültesi, sabriye@Jmu.edu.tr, Orcid: 0000-0002-1311-3333
} 


\section{Wordsworth in Hyderabad: Identity Crisis in Meena Alexander's Nampally Road}

Meena Alexander is an internationally acclaimed Indian poet, scholar and writer. She was born in Allahabad into a Syrian Christian family from Kerala, South India. Her father got a job in Khartoum, Sudan when she was at the age of 5. Meena Alexander graduated from Khartoum University in 1969, then moved to England for her PhD in English Literature and got her degree in 1973. Alexander returned to India and taught at several universities in Delhi and Hyderabad. She lived and worked in New York City where she was a distinguished Professor of English at Hunter College and the Graduate Center; City University of New York until her death in November, 2018. Meena Alexander wrote including several volumes of poetry, criticism, a memoir, essays, and two novels. Exile, identity crisis, search for roots, migration are discussed in the works of Meena Alexander. As Dolores Herrero states Meena Alexander is a daughter and writer of Indian diaspora and her writings reflect her own lived diasporic experiences: on the one hand those of uprooting, exile, trauma, separation, and loneliness, but on the other, those of hope and privileged multiple vision that can alone transcend rigid national and cultural barriers. (2007: 27). According to Nazari, Pirnajmuddin and Moradi, "in her postcolonial writings - poetry, novel, autobiography, criticism- Meena Alexander investigates the relationship between history and personal lives" (2018: 1). Rebecca Sultana points out that:

Alexander's writing disturbs and reconfigures the representations of the nation by situating her novels and personal narratives upon the politics of displacement. This displacement is figured in terms of a diasporic feminist vision that allows for a questioning of patriarchal narratives of nation and identity. In doing so, her texts also rewrite normative identity categories such as those of nation, race, gender and postcoloniality. (1999: 62)

Meena Alexander's first novel, Nampally Road (1991) is not an exception. This short novel is also about displacement and the protagonist's attempts to create herself an identity in her native land, India. This paper aims to explore the conflicts in the protagonist's life and identity crisis Mira experiences while searching for her self with the portrayal of in sociopolitical changes in Contemporary India.

Nampally Road is a short, semi-autobiographical novel. The novel is set in India, Hyderabad. The protagonist is Mira Kannadical. She is an English lecturer who returns to her own country after studying in England for four years and getting a $\mathrm{PhD}$ on Wordsworth from Nottingham University. She is uncomfortable and alone in England and decides to return her home country. This change in location becomes a new experiment for Mira. If she returns to India, she will be able to form a new identity and returning to India is the only solution to her anxiety and loneliness:

When I began my English sojourn I found myself at a great disadvantage as far as the loneliness of life was concerned. I suffered from dislocation. .... I felt my nerves all jangled with the effort. I was trapped in the effort to remake myself and all the Husserlian epistemology I studied, flat sere stuff filled with post-Cartesian precision that respected no one's soul, did nothing to help. The job offered in Hyderabad could give me a way out. I returned to India determined to start afresh, make up a self that had some continuity with what I was. (Alexander, 1991: 29,30)

Herrero, here, assumes that Mira tries to forge a sense of identity, an identity independent of her surroundings, amidst a world that strives to impose clear-cut and rigid definition, classifications, and labels upon people (2007: 38). Mira wants to meet new people and see 
new places. So, she accepts a teaching position in Hyderabad without thinking. As Hooda and Shikha state:

Meena Alexander, here, makes a reference to the origin of Nampally Road in her autobiography, Fault Lines. As the title of the memoir indicates, her sense of displacement or dislocation is such a strong sentiment, owing perhaps to the physical trajectory of her life, that she appears to struggle with lines, boundaries and environments in her work and self (2013:2).

When Mira reaches in Hyderabad, she acts like a strong woman rather than a little confused girl. In order to create herself a new identity against traditions and her past, she wants to write:

It was my fond hope that by writing a few poems, or a few prose pieces, I could start to stitch it all together; my birth in India a few years after national independence, my colonial education, my rebellion against the arranged marriage my mother had in mind for me, my years of research in England. How grotesque I had felt, how cramped and small, tucking myself day after day into a library seat, reading up on my chosen authors. Now in Hyderabad I was fully adult. In any case my mind had grown stronger. I could live my life. (Alexander, 1991: 30,31)

Hookha and Shikha assert that all Mira's hopes and dreams are shattered to see a totally different picture of India which teems with violence, civil unrest, and turbulence (2013:2). Mira finds herself trapped in the city. For Herrero, she tries to write and define her role and identity in relation to an India that is undergoing serious civil and social upheaval (2007: 39) She cannot comprehend what is happening in her country. Mira describes her own confusion as follows:

As for the Indian past, what was it to me? Sometimes I felt it was a motley collection of events that rose in my mind, rather like those bleached stones in the abandoned graveyard the boy picked his way through. I had no clear picture of what unified it all, what our history might mean. We were in it, all together. That's all I knew. And there was no way out. (Alexander, 1991:28)

While recollecting a glorious past, Mira is shocked to see the minister's "Ever Ready" men's violent attack in order to supress a demonstration by a group of orange sellers against the latest tax rise. In an environment where poverty and wealth exist together, Mira starts to question her own thoughts and writings. She realizes that her words make no sense in this world and her romantic philosophy is useless. Her PhD thesis subject, Wordsworth can no longer be her model. She questions her teaching of romantic poetry in India- " why study Wordsworth in our new India?" ( Alexander, 1991:54) She continues as:

It's a good question. I value Wordsworth for his great privacy of mind and his power. For his illuminations about memory. For his voice so refined that we can listen intently and then say, no our lives are not like that. We live with turmoil and disturbance, with the abuse of law. But, as a young man he knew a little about that too. Let me tell you. (Alexander, 1991: 54)

Dolores Herrero states that teaching western classics is quite at odds with her own history and with the environment in which she is teaching these texts (2007: 39). Later, Mira decides "no one needed my writing. It could make no difference" (Alexander,1991:28). Readjusting with the Indian society is not easy for Mira. She wants to become a poet in order to avoid from an arranged marriage. Mira strongly feels that "she may not be able to survive such a marriage and for her marriage was a personal matter and she will commit into a marriage only when she is fully prepared for the arrangement"(Alexander, 1991:33) However, 
Mira finds love in Hyderabad. Ramu is a college teacher like her. Both Mira and Ramu teach English in Sona Nivas, a local college. Mira wants to be a distinguished writer, but her lover, Ramu does not respect her literary efforts and forces her to devote herself to politics as passionately as he does. Ramu is not the only person around Mira. Durgabai (Little Mother), her students and Rameeza make her life more meaningful.

However, Mira finds herself in the middle of the protests against the repressive government's policies. Nazari et al. acknowledge that "the novel revolves around Mira's observation of the nation and its cultural infrastructures which result in reconsideration and redefinition of her national self "(2018: 3). In the beginning of the novel, Mira and Ramu are seen at a cafe on Nampally Road. Looking at the road from the window of a cafe, Mira feels amazed to see such a peaceful city:

The sellers of cheap airline tickets to Dubai, the housewives in their well-starched saris, cloth bags in hand stopping for a little refreshment on their way to the latest bargain at the SuperBazaar, whose red brick walls, though still unfinished, were studded for exotic effect with a cluster of polished stones from the local quarry where the Nizam once held his boar hunts (Alexander, 1991: 1-2).

Ramu tells her: "Keep looking, Mira, carefully now. We must use our eyes" ( Alexander, 1991:6). He believes that in order to change the world they live in, they have to look critically as intellectuals. Mira notices that suddenly this quiet and peaceful scene of the road changes into a site of anarchy because of the birthday celebration of Limca Gowda, the Chief Minister of Andhra Pradesh. Alexander describes Limca Gowda as "an ambitious man and wished to turn himself into an absolute ruler. His party which had been voted in four years ago, now rules with an iron hand" (1991: 4). Birthday celebrations of the Chief Minister turns quiet Nampally Road into a noisy place. For these celebrations, huge amount of state money which comes from taxes is spent. This makes people furious. Meanwhile, a woman called Rameeza is raped in police custody. Rameeza Bee is a young woman, accompanied by her husband to Sagar Talkies to see the celebrated "Isak Katha, the multimillion- rupee theological film based on the life of the young Isaac of the biblical fame" (Alexander, 1991: 20). Rameeza and her husband are surrounded by a group of drunken policemen on their way to home. She is gang raped and her husband has beaten to death. Nothing is done until the Limca Gowda's sixtieth birthday celebrations are over.

Mira realizes that "in the new Indian nation, there is no longer any space for the Gandhian nationalist narrative" (Alexander, 1991: 47). She remembers the past and says:

Just thirty years ago Gandhi had been living and breathing in this world. There was no need then of stone statues. "Father of the nation", it said in Devanagari script under the high pedestal... His eyes, polished lovingly by the sculptor and washed with years of sun and rain, stared into a future that had disowned him. What would he have made of us, our lives fractured into the tiny bits and pieces of a new India? Our thoughts were filmed over with so many images that the real no longer mattered: the march on the Street just a day ago, or the rape of an unknown woman, could vanish into the air, and someone like me could stand in front of a class with book open, mouthing unreal words (Alexander, 1991: 47).

As Nazari et al. point out "Gandhi's principle of "non-violence" does not accommodate to the new political and cultural state of affairs created by Limca Gowda's oppressive rule" (2018:5). For Hooda and Shikha, Mira's concept of nationalism is distorted by the neo-colonial elites who misuse their political power to assault and batter the poor, downtrodden people (2013:3). The climax of the novel, as Herrero states, " is the rape of Rameeza Be, a poor Muslim woman, by a group of policemen" (2007 :40). The rape of 
Rameeza Be by drunken policemen becomes the climax of the novel. Actually, Alexander is influenced by a real story of the rape of a Muslim woman Rameeza. Hooda and Shikha tells this story:

On March 30,1978 when she was returning from a late night movie show with her husband, Rameeza dragged and detained in the police station where she was raped and beaten the whole night. Her husband was beaten to death when he refused to pay four hundred rupees to the police (2013:3).

In order to take revenge of the gangrape of Rameeza Be, the angry community in the novel, burns the police station and frees Rameeza from police custody. As a consequence, a curfew is imposed in Hyderabad in the days leading up to a general election. Hooda and Shikha put it as follows:

Alexander depicts the grim reality of senseless political violence, where the authoritarian rule and reign of the corrupt chief minister Limca Gowda creates a political climate that curbs freedom of expression. This is where the novel offers a perfect blend of fact and fiction, portraying an India that teemed with terror, violence, confusion and turmoil, thus adding to Mira's sense of disquiet about the choices she has made in her own life and those of the country and people in power (2013:3)

According to Sasikanth, Mira's search for identity makes a sharp turn when she sees Rameeza Bee for the first time inside the Gowliguda police station (2013: 140). Someone carries away Rameeza to the house of Maitreyiamma where she is given good rest and medical attention. Ramu and Mira visit Rameeza in that house and her desparate condition extremely influences Mira. When Rameeza, the victim is interviewed by Mira, all that she can do is make little whispers and short cries. Ramu and Mira want to understand her pain. They tell her that "those who raped her will be brought to justice and that people would rise up against violence" (Alexander 1991: 80) Mira says 'I could give up my own useless life in some way that could help her' (Alexander,1991: 82). This is the point where Mira finally finds her identity. She understands that she is just an ordinary Indian woman. Sasikanth makes the remark that :

The suffering of Rameeza Be is the suffering of an entire nation and Mira's mission in life was to seek a solution to give relief to millions of Rameezas in India. Mira becomes half an Indian by returning to India and decides to settle down permanently here. She becomes a full Indian when she understands that her mission in life is to serve India, her motherland. (2013: 140)

Meena Alexander talks about Nampally Road in an interview between Zainab Ali and Dharini Rasiah and she explains her aim in this novel as follows:

What I try to do is give voice to these very simple human experiences of longing and love and loss- all the stuff that makes us what we are- but within this complicated, unstable world, shifting within diasporic and migrant spaces, where identities are contested, where they cannot be taken for granted. Because that's the world I know (2000: 88)

Through this statement, Meena Alexander reveals her own anxiety caused by dislocation and her ongoing search for self. Nazari et. Al write that "in this semiautobiographical work, Mira, similarly to Alexander, undergoes dislocations, alienation, and cultural displacement which results in anguish and personal turmoil" ( 2018: 9). Kazım Ali divides the action of the novel into two distinct courses: 
While the internal story is the classic tale of a young woman in existentialist crisis about who she is and what her place is in the world, the external story is about a political crackdown and imposing of curfew in Hyderabad in the days leading up a general election, following the suspected gang rape of a village woman and murder of her husband by the local police force, cronies of the current imcumbent minister Limca Gowda. (2009: 61)

In conclusion, it can be said that Mira feels uncomfortable and alone in England and comes to her own land in order to meet new people and see new places.Hoewever, she is stuck in the middle of a turmoil. In the end of the novel, it is difficult to see a change in the socio political environment of Hyderabad. Despite all these, Mira Kannadical manages to redefine her identity with the help of her education in England, her passionate activist lover, Ramu and especially the rape of Rameeza Be by the policemen and truly defines herself as an ordinary Indian woman.

\section{REFERENCES}

Alexander, Meena. (2013). Nampally Road. Chennai: Orient Black Swan.

Ali, Kazım. (2009). The Stone-Eating Girl: How a Text Keeps its Secret. In L. Basu, C.Leenerts (Eds), Passage to Manhattan: Critical Essays on Meena Alexander, 51-69: Newcastle Upon Tyne: Cambridge Scholars Publishing.

Ali, Zainab \& Dharini Rasiah.(2000) Interview with Meena Alexander. In King-Kok Cheung (ed.) Words Matter: Conversations with Asian American Writers, 69-91: Honolulu: University of Hawaii Press.

Fahimeh Nazari, Hossein Pirnajmuddin\& Namatollah Moradi (2018). Postcolonial National Space in Meena Alexander's Nampally Road. Journal of Language, Literature and Culture, 65:1, 1-10.

Herrero, Dolores (2007). Meena Alexander's Transgressive/ Diasporic Female Characters: Healing Wounds and Fracturing the Iconic Feminine and the Language of the Colonizer. South Asian Review, 28:2, 27-46.

Hooda, Archana\& Shikha, Ms.(April 2013). Dislocated Self as Reflected in Meena Alexander's Nampally Road. The Criterion An International Journal in English, Vol IV. Issue II, 1-6.

Sasikanth, John Wesley. The Plight of Women in Post Colonial India as Portrayed in Meena Alexander's Nampally Road. Research Journal of English Language andf Literature. Vo.1. Issue 1. (2013), 139-142.

Sultana, Rebecca. Rewriting Nationalism: A Comparison of the The Tiger's Daughter and Nampally Road. Conference of College Teachers of English Studies. 64 ( Sept.1999), 62-70. 